\title{
Implementation of National Examination Exemption and Free Learning to Improve the Quality of Education in Junior High School I Banyuasin III
}

\begin{abstract}
Siti $\operatorname{Hadiah}^{1 *)}$
${ }^{1}$ SD Negeri 6 Banyuasin III

Corresponding author. E-mail: diahtaupik123@gmail.com

ABSTRACT

There are indications that the quality of Indonesian education is still lacking among the releases issued by the PISA agency. Regarding the quality of education, the research problem is the implementation of national lessons and independent learning to improve the quality of education at SMP Negeri 1 Banyuasin III. The research method used was qualitative with the research subjects were the principal and teachers at SMP Negeri 1 Banyuasin III. The data techniques used were interviews, observation and documentation study. The data analysis technique used consists of data reduction, data presentation and conclusion drawing. The triangulation of this study is the result of field observations conducted by researchers at SMP Negeri 1 Banyuasin as well as a study of existing documentation. The results of income triangulation show that improving the quality of education can be carried out by planning, implementing, evaluating and reflecting on learning activities from independent and learning policies.
\end{abstract}

Keywords: Implementation, National Examination Exemption, Freedom of Learning

\section{INTRODUCTION}

The quality of education is a problem that has become a challenge for the Indonesian nation from time to time. In recent years, the triennial release of the PISA (Program for International Student assessment) has always provided a sad picture of the low proficiency of Indonesian students.

Still reflecting on the blurry results of the PISA evaluation, the education (education) page of the Kompas news daily (kompas.com, Sunday, April 5, 2020), said that the minister of education and culture, Nadiem Makarim, prepared 5 (five) strategies to carry out holistic learning to develop Indonesia's superior human resources.

The five strategies are: a more selective method of selecting school principals, creating a "new" generation of teachers, simplifying the curriculum, assessing the minimum competencies as a substitute for the national exam and optimizing the use of ICT in learning. encouragement or motivation.

Related to the above problems, this research will discuss the implementation of the exemption of the National Examination and Free Learning towards the quality of education in Banyuasin III sub-district, Banyuasin Regency.

\subsection{Quality of Education}

The quality of education is a measure of the success rate of the education process in a country.
Quality education will affect various aspects of the country's life [1]. [2] argues that education quality is a function of an effective learning process, leadership, teacher participation, student participation, management, organization, physical environment and resources, school customer satisfaction, input and facilities support, and school culture.

Quality education refers to two things, namely process and results [3]. [4]wrote several components related to the quality of education, namely: quality of input (students, infrastructure, human resources), process quality (teacher quality, learning quality, student learning quality, managerial quality), output quality (academic and Non-Academic).

\subsection{Exception of National Examination}

Education as a process requires evaluation. There are at least three main reasons why education needs evaluation. First, from a process point of view, there is interdependence between the three components (teaching objectives, materials, and teaching and learning methods). Second, the objective will direct how the implementation of the teaching and learning process (material, teaching and learning methods) should be implemented, third, is a reference frame for evaluating learning outcomes [5]National examinations have been carried out for many years. From starting to be called the state exam, ebtanas, the national final exam or UAN and finally since 2005 it was called the national exam or UN [6] In 2019, the government 
declared that the national exams would be stopped. There are at least three reasons behind the policy being taken. 1. National exams have so far only tested low order thinking skills 2. National exams do not encourage teachers to always carry out meaningful learning for students and 3. National exams are not optimal in boosting the quality of national education.

\subsection{Freedom of Learning}

Equitable education for a country as big and as wide as Indonesia is a work which is not only very important and noble but also hard and takes energy, time and money. However, as mandated by law, education and equitable education are things that must be implemented by the state.

Fathurrochman [7] said that the concept of independent learning is that students feel comfortable learning and discussing with the teacher, because learning does not have to be in class, it can be carried out with outing classes by not only listening to explanations from the teacher but rather shaping the character of students, who are brave. independent, clever in socializing, civilized, polite and competent.

The essence of Independent Learning is to explore the greatest potential of teachers and students to innovate and improve the quality of learning independently.

\subsection{Relevant Research Results}

Fathurrochman [8] entitled "The Principal's Vision as a Driver of Educational Quality" The results of the EHara research study concluded that the concept of the Principal's Vision as a driver of Educational Quality is expected to overcome the problem of low quality education by optimizing all the resources available in schools.

Research by Ristianti [9] was entitled "ComputerBased National Exam Swot Analysis." This study analyzes the strengths, weaknesses, opportunities and challenges faced by schools in implementing computerbased school exams.

Although the discussion focuses on the SWOT analysis of the implementation of the computer-based national exam (UNBK), research by Pernamawati, et al. provide adequate reference material for efforts to develop a logical framework for the author's research discussing exemption from national exams.

\section{METHODS}

This research is a qualitative research conducted at SMP Negeri 1 Banyuasin III and takes place between August and November 2020. Data collection was carried out in several ways, such as using interviews, observation and documentation.

The research questions to be answered in this study are: 1. How do principals and teachers carry out the
Competency Assessment and Character Survey?

2. What should be done by principals and teachers in improving the quality of education for both teachers and students?

3. What are the facilities and infrastructure and resources that can support efforts to improve the quality of education?

4. What should be implemented by school principals and teachers in implementing the curriculum and learning process for independent learning?

5. How is the impact of the Exemption of National Examination and Freedom of Learning on education quality?

6. What is the principal's policy in an effort to encourage teachers to be creative, innovative, and master the strategies, models and approaches of $21 \mathrm{st}$ Century Learning?

\section{RESULTS AND DISCUSSION}

The results showed that the answers given by the informa, both the principal and the teachers who were the research subjects, were in conformity and got good results and were in accordance with the focus and research questions

Freedom of learning is a policy based on the philosophy that every human child has the right to learn and obtain learning in accordance with their natural traits and talents [10] [11] [12].

SMP Negeri 1 Banyuasin III has implemented the concept of independent learning, shows that the teaching and learning process is carried out in an atmosphere of adaptation to new habits (AKB), 3M (maintaining distance, wearing masks and washing hands). The teacher provides learning based on the RPP (lesson plan) during the pandemic which is an adjustment to learning tools in normal situations [13] [14] [15].

SMP Negeri 1 Banyuasin III is ready to implement the national exam exemption program by carrying out competency assessments and character surveys. The results of interviews with the school principal, it was found that SMP Negeri 1 Banyuasin III had prepared various tools needed to carry out competency assessments and character surveys [16].

\section{CONCLUSION}

The exemption of the national exam (UN) is a kemendibud policy which has been launched since the end of 2019. The implementation of the policy is planned to start in 2021 or in the 2020/2021 school year. SMP Negeri 1 Banyuasin III has anticipated these changes. Learning devices, starting from the KTSP document for the 2020/2021 school year, began to include assessment activities and character survey. 
Teachers are given the opportunity to take part in workshops, technical guidance regarding minimum competency assessment and character surveys. SMP Negeri 1 Banyuasin III also facilitates the implementation of in-house training through MGMP for as many teachers as possible, increasing their competence in the field of AKM and Character surveys.

Freedom of Learning. The free learning policy, which provides the widest possible opportunity for teachers and students to develop what they have, to learn what they are interested in, is fully supported by the leadership ranks at SMP Negeri 1 Banyuasin III.

Freedom of learning, based on the observations and findings of researchers at SMP Negeri 1 Banyuasin III, has great potential in contributing to improving the quality of education at SMP Negeri 1 Banyuasin III, especially in the long term.

Improving the quality of education can be carried out by planning, implementing, evaluating and reflecting through the activities of exemption from national exams and the policy of free learning.

The policy program for exemption from national exams and freedom of study should be implemented with should be carried out with all the effort. The successful implementation of both, gives great hope for the improvement of the quality of education which in the end also means the improvement of Indonesia's face.

\section{ACKNOWLEDGMENT}

The author would like to thank Dr.H. Bukman Lian, M.M., M.Si., Chancellor of the PGRI Palembang University, Dr. Syaiful Eddy, M.Sc., Director of the Postgraduate Program at the PGRI Palembang University, Dr. Happy Fitria, M.Pd., Head of Education Management Study Program and all those who have helped morally and materially. May the goodness become multiple good deeds.

\section{REFERENCES}

[1] Sudarsana, I.K. (2016). Peningkatan Mutu Pendidikan Luar Sekolah dalam Upaya Pembangunan Sumber Daya Manusia. Jurnal Penjaminan Mutu. Vol. 1. No. 1. 1-14

[2] Sallis, E. (2010). Total Quality Management in Education, Manajemen Mutu Pendidikan. Jogjakarta: IRCiSoD.

[3] Umar, M., \& Ismail, F. (2017). Peningkatan Mutu Lembaga Pendidikan Islam (Tinjauan Konsep Mutu Edward Deming dan Joseph Juran.) Jurnal Pendidikan Islam Iqra'. Vol. 11 No. 2. 14-24

[4] Zubaidah, Siti. (2015). Pengaruh Budaya Sekolah dan Motivasi Kerja Guru Terhadap Mutu Pendidikan di SMK N 1 Pabelan. Prosiding
Seminar Nasional Pendidikan UNS \& ISPI Jawa Tengah 2015

[5] Sartina., Nursiang., Faisal. (2020). Analisis Kebijakan Ujian Nasional Terhadap Evaluasi Akhir Pendidikan. Jurnal Mappesona IAIN Bone. Vol. 2. No. 2. 1-18

[6] Asiah, S., Rofieq, A. (2017). Analisis Kebijakan Ujian Nasional Tingkat Sekolah Menengah Kejuruan (SMK). Jurnal Edukasi. Vol. 3 No. 1. 75-92.

[7] Fathurrochman, I., Hariani, D., Hamengkubuwono, H., Arsil, A., Muhammad, A., \& Ristianti, D. H. (2020). The Development of Student Academic Administration Services in Higher Education. International Journal of Psychosocial Rehabilitation, 24(8), 4764-4771.

[8] Ristianti, D. H. (2018). Psikologi Lintas Budaya.

[9] Mu'amalah, K. (2020). Merdeka Belajar Sebagai Metode Pendidikan Islam dan Pokok Perubahan (Analisis Pemikiran K. H. Hamim Tohari Djazuli). Jurnal Tawadhu. Vol 4.No. 1. 977-994

[10] Harapan, E. (2016). Visi Kepala Sekolah Sebagai Penggerak Mutu

[11] Pernamawati, S., Kristiawan, M., Fitria, H. (2020). Analisis Swot Ujian Nasional Berbasis Komputer. Jurnal Manajemen, Kepemimpinan, dan Supervisi Pendidikan Univ. PGRI Palembang. Vol. 6. No. 1. 112-123.

[12] Ristianti, D. H., \& Fathurrochman, I. (2020). Penilaian Konseling Kelompok. Deepublish.

[13] Abidah, A., Hidayatullah, HN., Simamora, RM., Fehabutar, D., Mutakinati. (2020). The Impact of Covid-19 to Indonesian Education and Its Relation to the Philosophy of "Merdeka Belajar". Jurnal Studies in Philosophy of Science and Education (SiPoSE). Vol. 1. No. 1. 38-49.

[14] Eva, E., Yosro, N., Ristianti, D. H., Kusen, K., \& Fathurrochman, I. (2020). Eksistensi Guru Pendidikan Agama Islam dalam Pembentukan Karakter Peduli Lingkungan Peserta Didik. JOEAI: Journal of Education and Instruction, $3(2), 172-178$.

[15] I. Fathurrochman, S. Danim, S. Anwar AB, N. Kurniah, and D. H. Ristianti. (2021). "Theoretical Review of the Implementation Islamic Boarding School Curriculum Management in Indonesia," Int. J. Educ. Res. Dev., vol. 1, no. 1, pp. 1-15.

[16] I. Fathurrochman, S. Danim, S. Anwar AB, and N. Kurniah. (2021). "The School Principals' Role in Education Management at the Regional Level : An Analysis of Educational Policy in the Industrial Revolution 4 . 0," Adv. Soc. Sci. Educ. Humanit. Res., no. 532, pp. 237-242 